\title{
Pemanfaatan Energi Matahari Sebagai Energi Bersih yang Ramah Lingkungan
}

\author{
Muhammad Ali, Jaka Windarta \\ Magister Energi, Sekolah Pascasarjana, Universitas Diponegoro; \\ Email : muhammadali@students.undip.ac.id (M.A), jakawindarta@lecturer.undip.ac.id (J.W);
}

\begin{abstract}
Abstrak : Pemanfaatan energi primer yang baru dan terbarukan mulai banyak di terapkan di berbagai negara, dikarenakan berkurangnya sumber bahan baku energi primer yang berasal dari fosil (minyak bumi, gas dan batubara). Usaha untuk menggantikan energi primer yang berasal dari fosil selain dari berkurangnya cadangan baik minyak bumi, gas dan batubara, juga disebabkan karena pengaruh emisi gas buang dari pemanfaatan energi primer dari fosil. Energi primer dari fosil dalam setiap perubahan bentuk energinya seringkali menggunakan teknologi insinerasi yang menyebabkan peningkatan emisi karbondioksida sehingga dapat berakibat buruk terhadap lingkungan dan mempengaruhi perubahan iklim. Dalam makalah ini penulis menitikberatkan pemanfaatan energy primer dari matahari menjadi energi final yang dapat secara langsung dimanfaatkan dan juga tidak mengeluarkan emisi karbondioksida. Pemanfaatan energi matahari secara thermal diharapkan mampu meningkatkan efisiensi dengan menggantikan atau mensubtitusi teknologi insinerasi yang biasanya digunakan untuk merubah energi primer menjadi energi thermal. Penggunaan sumber energi yang ramah lingkungan dengan menggunakan energi matahari ini diharapkan mampu mengurangi efek Gas Rumah Kaca dan dapat mencegah perubahan iklim yang ekstrim.
\end{abstract}

Kata Kunci : Energi Matahari, Thermal Energy, Ramah Lingkungan

\section{Pendahuluan}

Pemenuhan kebutuhan energi primer menjadi hal yang sangat penting seiring kemajuan teknologi dan pertumbuhan penduduk. Kebutuhan energi primer sampai dengan saat ini pemenuhannya masih bergantung dari energi fosil (minyak bumi, gas bumi dan batubara). Pemerintah telah melakukan berbagai cara untuk memenuhi kebutuhan energi primer antara lain melalui: penambangan Minyak dan gas bumi bahkan menambah volume import, namun hal itu belum mampu untuk memenuhi kebutuhan energi primer di Indonesia (Badan Pengkajian dan Penerapan Teknologi, 2019).

Pemanfaatan sumber energi primer berbahan fosil dalam perubahan bentuknya menjadi energi final (energi yang langsung dapat dimanfaatkan, contohnya: energi listrik, bahan bakar, dlsb), seringkali menimbulkan efek yang buruk bagi lingkungan salah satunya: meningkatnya emisi gas buang karbondioksida. Pencemaran emisi gas karbondioksida pada tahun 2016 tercatat sebesar 97,9 juta ton emisi karbondioksida. Pencemaran udara oleh emisi gas karbondioksida ini dapat memicu terjadi perubahan iklim yang ekstrim dan bencana alam sebagai contohnya: terjadinya hujan asam 
Vol. 1, No. 3, pp $68-77$

doi: $10.14710 /$ jebt.2020.10059

dan bencana alam puting beliung (Badan Pusat Statistik, 2018). Dampak buruk bagi lingkungan dan perubahan iklim menjadi gagasan untuk penulis memanfaatkan energi matahari dengan aplikasi thermal untuk meningkatkan efisiensi energi dan dapat diterapkan di Indonesia. Penggunaan energi matahari ini juga akan menurunkan kadar emisi karbondioksida dan tentunya akan berpengaruh baik terhadap lingkungan (Barranco et al., 2016). Pemanfaatan energi matahari ini digunakan dengan cara mengumpulkan panas matahari untuk menghasilkan fluida panas (steam) yang diperoleh melalui radiasi sinar matahari sehingga dapat meningkatkan efisiensi energi dan mengurangi emisi karbondioksida (Claes G. Granqvist \& Niklasson, 2018). Pemanfaatan sinar matahari juga dapat diterapkan dalam sistem bangunan ataupun rancang gedung sehingga dapat memanfaatkan energi dari matahari sebagai energi primer menjadi energi final yang langsung dapat dimanfaatkan (Pencahayaan, Pemanasan air maupun sebagai energi listrik).

\section{Material dan metode}

Perpindahan energi dari matahari sampai ke bumi melalui metode radiasi, dimana radiasi elektromagnetik menjadi dasar radiasi thermal melalui benda hitam atau yang dikenal sebagai spektrum Plank. Hukum Plank menyatakan konsekuensi dari sifat kuantum radiasi ditunjukkan dalam Gambar 1 (Claes G. Granqvist \& Niklasson, 2018).

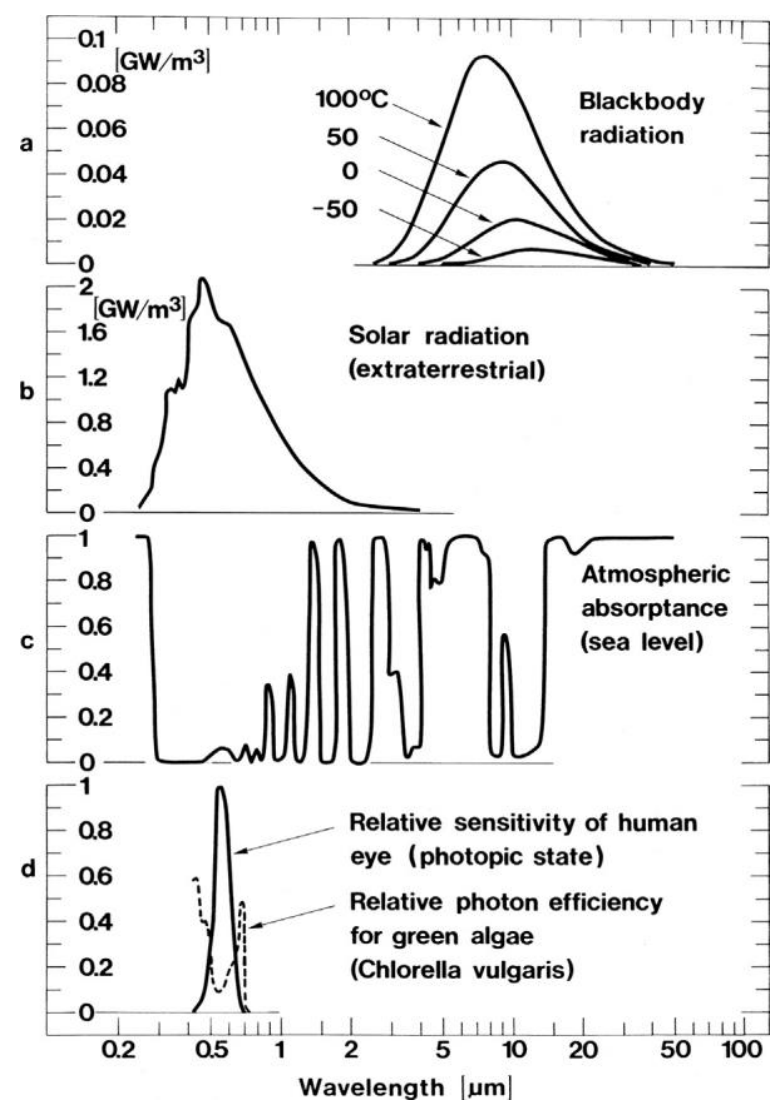

Gambar 1. (a) Spektrum Radiasi Benda Hitam pada Empat Temperatur

(b) Spektrum Radiasi Matahari di Luar Atmosfer Bumi

(c) Spektrum Absorpsi Khas Secara Vertikal di Seluruh Atmosfer

(d) Spektrum Sensitivitas Relatif Mata Manusia dan Efisiensi Fotosintesis Relatif untuk Tanaman

Hijau (Claes G. Granqvist \& Niklasson, 2018) 
Gambar 1 menunjukkan bagian penting dari radiasi ambien, yaitu selektivitas spektral. Dengan kata lain, radiasi di sekitar kita dibatasi dalam interval panjang gelombang yang spesifik dan seringkali ditentukan dengan baik (Claes G. Granqvist \& Niklasson, 2018).

Spektrum (a) pada gambar 1 mengilustrasikan spektrum yang berkaitan dengan empat suhu. Skala vertikal menyatakan daya per satuan luas dan panjang gelombang increment (karenanya unit $\left.\mathrm{GW} / \mathrm{m}^{3}\right)$. Spektrum berbentuk seperti lonceng dan terletak pada rentang panjang gelombang $2<\lambda<$ $100 \mu \mathrm{m}$. Puncak spektrum bergerak menuju panjang gelombang yang lebih pendek digambarkan sebagai suhu naik, puncaknya pada $\sim 10 \mu \mathrm{m}$ untuk suhu kamar. Radiasi dari suatu material diperoleh dengan mengalikan spektrum Planck dengan faktor numerik, yang dikenal sebagai emisi. Emisi bergantung pada panjang gelombangnya.

Spektrum (b) pada gambar 1 menunjukkan spektrum radiasi matahari di luar atmosfer bumi. Radiasinya berbentuk lonceng yang mendefinisikan suhu permukaan matahari, yaitu $\sim 5.500^{\circ} \mathrm{C}$. Spektrum matahari terbatas pada $0,25<\lambda<3 \mu \mathrm{m}$, sehingga tidak ada tumpang tindih dengan radiasi termal, sehingga dapat dipisahkan antara termal dan radiasi matahari. Area terintegrasi di bawah spektrum matahari memberi "konstanta matahari" $\left(1.353 \pm 21 \mathrm{~W} / \mathrm{m}^{2}\right)$. Sistem konversi energi surya biasanya terjadi di permukaan tanah, hal ini menjelaskan bagaimana penyerapan atmosfer mempengaruhi iradiasi matahari dan emisi panas.

Spektrum (c) dari gambar 1 menunjukkan spektrum serapan karakteristik secara vertikal pada saat kondisi langit cerah. Spektrum ini sangat kompleks dan mengandung pita dengan daya serap tinggi - terutama karena uap air, karbon dioksida, dan ozon - dan pita dengan transparansi tinggi. Sebagian besar energi matahari yang mencapai tanah memiliki radiasi ultraviolet $(\lambda<0,4 \mu \mathrm{m})$ dan inframerah $(\lambda>0,7 \mu \mathrm{m})$. Kepadatan daya maksimum di sudut kanan ke matahari adalah $\sim 1.000$ $\mathrm{W} / \mathrm{m}^{2}$. Radiasi termal dari permukaan di bawah langit cerah sangat kuat diserap, kecuali dalam interval $8<\lambda<13 \mu \mathrm{m}$ dimana transmitansi besar selama kelembapan tidak terlalu tinggi.

Spektrum (d) dari gambar 1 menunjukkan dua sifat biologis yang sangat relevan didalam bangunan. Kurva padat menggambarkan sensitivitas relatif mata manusia dalam kondisi siang hari, kurva berbentuk lonceng ada di $0,4<\lambda<0,7 \mu \mathrm{m}$ range dengan puncak $0,55 \mu \mathrm{m}$. Itu adalah bukti sebagian besar energi matahari adalah radiasi infra merah yang tidak terlihat. Kurva yang putusputus menunjukkan efisiensi fotosintesis dan menunjukkan tanaman itu menggunakan cahaya dengan panjang gelombang yang kira-kira sama dengan yang diterima oleh mata manusia.

Panjang gelombang dari radiasi sinar matahari ini dapat dirumuskan dengan hukum kekalan energi sebagai berikut :

$$
\mathrm{T}(\lambda)+\mathrm{R}(\lambda)+\mathrm{A}(\lambda)=1
$$

Dimana $T, R$ dan A menunjukkan transmitansi, reflektansi dan absorptansi, masing-masing. Persamaan lain yang menjadi dasar konservasi energi, yaitu

$$
\mathrm{A}(\lambda)=\mathrm{E}(\lambda)
$$

Di mana $\mathrm{E}$ adalah emisi, yaitu fraksi radiasi benda hitam. (sifat dari cahaya matahari dan termal, sering disebut sebagai $X_{\text {lum }}, X_{\text {sol }}$ dan $X_{\text {therm }}$, masing-masing, dengan $X$ menjadi $T, R, A$ atau E.) Perpindahan thermal dari energi matahari dalam penulisan karya ilmiah ini akan dibahas melalui beberapa material atau bahan. 
Vol. 1, No. 3, pp $68-77$

doi: $10.14710 /$ jebt.2020.10059

\section{Hasil dan pembahasan}

Perpindahan thermal dari sinar matahari umumnya dengan menggunakan alat solar thermal converter. Alat ini berguna untuk mengumpulkan sinar matahari sebelum di konversikan ke dalam bentuk energi lain.

\subsection{Solar Thermal Converter}

Solar thermal converter terdiri dari beberapa jenis, yang paling umum adalah kolektor atap dengan pelat datar peredam atau dengan peredam yang ditempatkan di dalam tabung kaca yang di vakumkan dan tipe ketiga menggunakan reflektor palung parabola linier yang mengarahkan radiasi matahari terhadap kolektor tubular dan digunakan untuk produksi tenaga, dan tipe keempat menggunakan bidang bidang yang dikendalikan secara individual cermin untuk memusatkan radiasi matahari ke penyerap yang terletak di pusat di menara. Konversi yang efisien terjadi saat menyerap matahari permukaan dalam kontak termal yang baik dengan fluida atau gas dan kapan kerugian termal ke suasana diminimalkan. Untuk sebagian besar aplikasi, penyerap harus ditempatkan di belakang penutup transparan surya yang kaku, dan bahan isolasi termal transparan dapat diintegrasikan di rancangan (Wàckelgard et al., 2001).

Bagian belakang dan samping kolektor surya harus termal terisolasi dengan baik. Komponen paling penting untuk foto-termal yang efisien konversi permukaan penyerap surya, yang pasti memiliki nilai yang besar dari Asol. Kehilangan panas radiatifnya harus diminimalkan, yang menuntut $\mathrm{E}_{\mathrm{therm}}$ rendah. Absorber yang tidak transparan, dan persyaratannya di atas dapat dimodelkan dengan persamaan :

$$
\begin{gathered}
\mathrm{R}(\lambda)=0 \text { untuk } 0,3<\lambda<\lambda_{\mathrm{C}} \mu \mathrm{m} \\
\mathrm{R}(\lambda)=1 \text { untuk } \lambda_{\mathrm{C}}<\lambda<50 \mu \mathrm{m}
\end{gathered}
$$

Dimana $\lambda_{\mathrm{C}}$ menunjukkan panjang gelombang "kritis" atau "cut-off" antara 2 dan $3 \mu \mathrm{m}$ tergantung pada suhu operasi kolektor surya dalam gambar 2 (C G Granqvist, 2003).

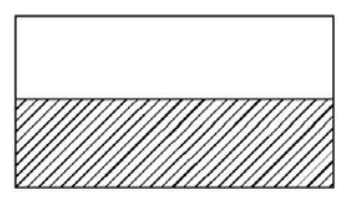

Intrinsic selective
material
Substrate
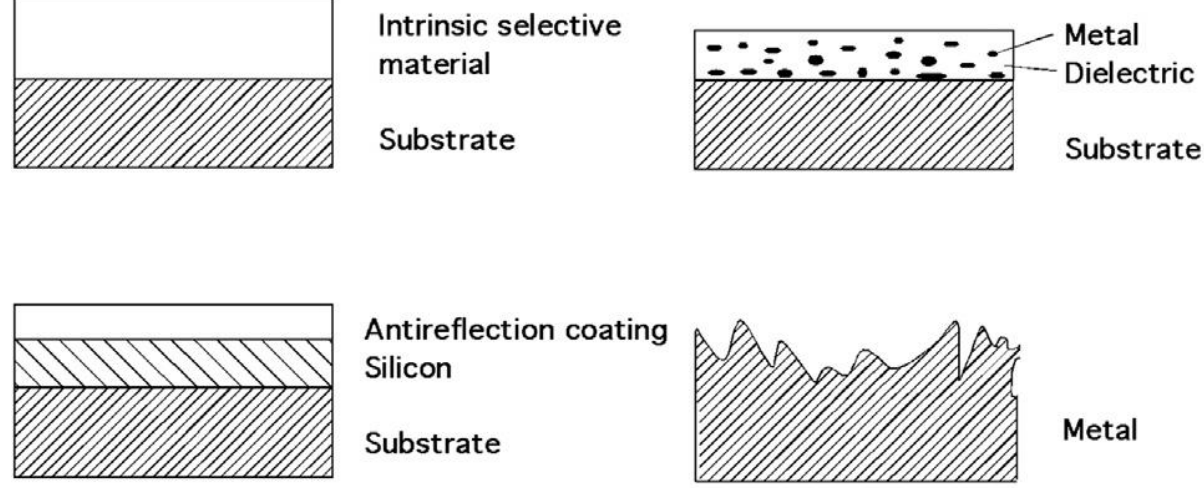

Antireflection coating Silicon

Substrate

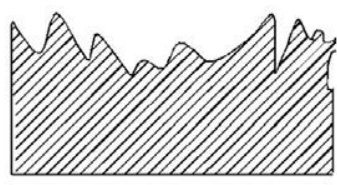

Metal
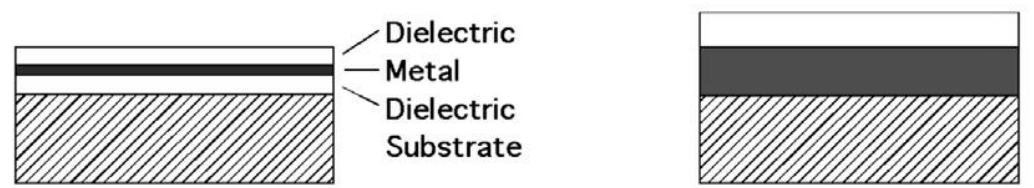

Doped tin oxide

Black enamel

Substrate

Gambar 2. Desain Skema Penampang dari Enam Jenis Lapisan Tipis dan Perlakuan Permukaan Untuk Penyerapan Energi Matahari Secara Selektif (C G Granqvist, 2003) 
Kerugian refleksi menjadi sebab pengurangan $\mathrm{A}_{\text {sol }}$ sehingga yang menyebabkan perawatan antirefleksi menjadi rumit. Film multilayer logam-dielektrik mewakili kemungkinan lain dan dapat disesuaikan sehingga mencapai penyerapan selektif matahari yang efisien energi (Choy, 2015).

Multilayers mengandung nanokomposit logam-dielektrik, dielektrik dan logam sangat diminati. Komposit memiliki nanopartikel logam tertanam dalam inang dielektrik, sering kali menjadi oksida, dan sering disebut sebagai bahan keramik-logam ("cermet"). Ini prinsip desain terakhir menawarkan banyak fleksibilitas, dan optimalisasi selektivitas spektral dapat dilakukan sehubungan dengan pemilihan konstituen bahan, ketebalan film, konsentrasi nanopartikel dan grading dengan kedalaman, dan bentuk serta orientasi nanopartikel. Nanopartikel jauh lebih kecil daripada panjang gelombang yang relevan dengan matahari atau termal radiasi, dan komposit merupakan "media efektif" yang sifat optik terletak di antara logam dan dielektrik (Kylili \& Fokaides, 2017; Niklasson \& Granqvist, 1984).

\subsection{Spectrally Selective Thin Films}

Sejumlah film tipis selektif spektral, dilapisi pada substrat logam oleh salah satu teknologi film tipis dan telah dikembangkan di masa lalu, dan beberapa dari film ini bersifat komersial produk. Filmfilm ini biasanya memanfaatkan beberapa desain prinsip dan mekanisme fisik yang disebutkan di atas. Teknik elektrokimia telah digunakan selama beberapa dekade hingga membuat permukaan selektif spektral cocok untuk kolektor surya pelat datar. Permukaan tipikal memiliki lapisan elektrodeposisi yang mengandung $\mathrm{Cr}$ atau Ni (diketahui sebagai "chrome hitam" dan "nikel hitam", masing-masing) dengan kompleks komposisi. Kurva padat pada Gambar 3 menunjukkan $\mathrm{R}(\lambda)$ untuk film, $\mathrm{A}_{\text {sol }} \approx 96 \%$ dan $\mathrm{E}_{\text {therm }} \approx 15 \%$ pada $100^{\circ} \mathrm{C}$ tipikal untuk jenis permukaan ini (Soum-Glaude et al., 2017).

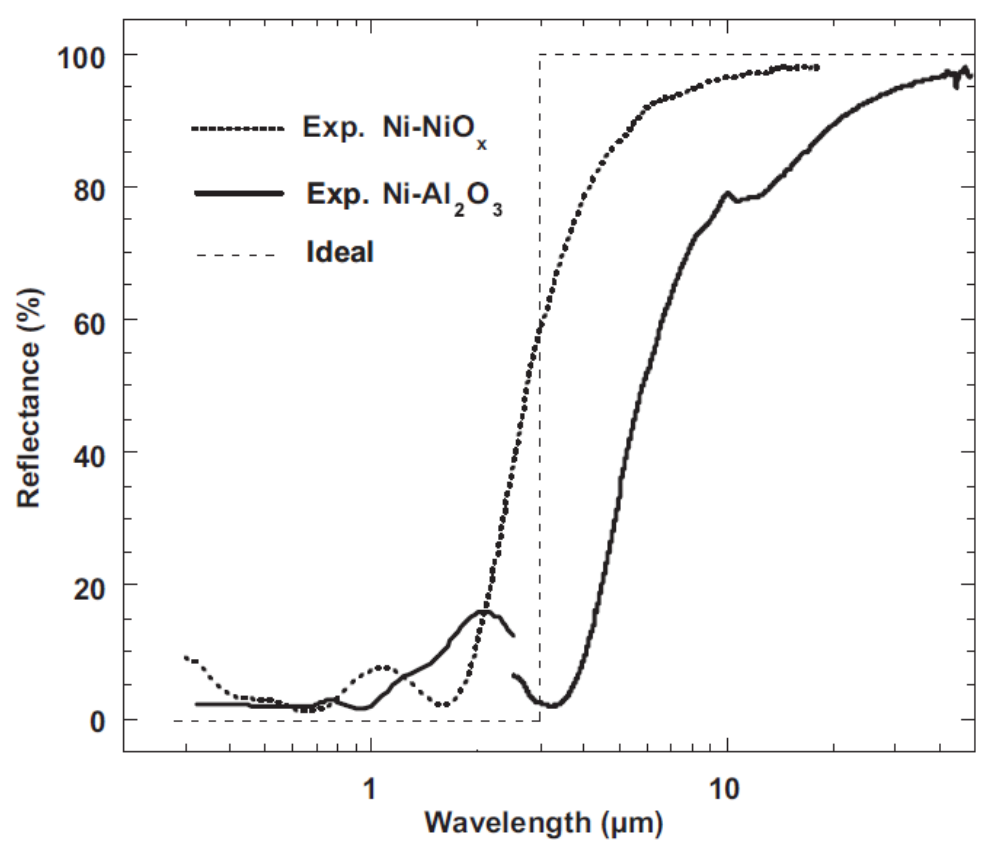

Gambar 3. Reflektansi Spektral untuk Dua Jenis Permukaan Penyerap Matahari Secara Selektif.

Garis Putus-Putus Menunjukkan Kinerja yang Ideal (Wàckelgard et al., 2001) 


\subsection{Spectrally Selective Paints}

Cat memiliki aset yang jelas karena dapat diaplikasikan secara umum teknik yang tersedia. Biasanya pigmen yang sangat menyerap, seperti Oksida berbasis $\mathrm{FeMnCu}$, dicampur dengan polimer transparan inframerah pengikat seperti silikon atau siloksan. Cat diaplikasikan dengan ketebalan $2-3$ $\mu \mathrm{m}$ pada substrat logam dengan Etherm rendah. Ciri data kinerja adalah $\mathrm{A}_{\mathrm{sol}} \approx 90 \%$ dan $\mathrm{E}_{\text {therm }} \approx 30 \%$, yaitu, bukan sebagai bagus untuk film tipis. Menurunkan emisi cat membutuhkan pengencer pelapis dengan konsentrasi pigmen yang lebih tinggi dan menyebabkan masalah daya tahan cat. Selektif spektral tidak peka terhadap ketebalan cat sehingga dapat diaplikasikan dengan memasukkan serpihan logam ke dalam pengikat/ Kolektor (Sani et al., 2017).

Selektivitas spektral dalam perkiraan sesuai dengan Persamaan (5) dan (6) telah dicapai barubaru ini dengan lapisan ganda $\mathrm{Si}_{3} \mathrm{~N}_{4} / a$-Si dan dengan oksida pelapis multilayer yang didukung oleh logam serta dengan menggunakan resonansi permukaan-fonon di nanopartikel $\mathrm{SiC}$ dan / atau $\mathrm{SiO}_{2}$ tertanam dalam foil polimer yang didukung oleh Ag. Tes praktis dengan optimal alat pendingin (terlindung dari sinar matahari langsung) mendemonstrasikan sebuah penurunan suhu rata-rata sebanyak $37^{\circ} \mathrm{C}$ selama penuh siklus siang-malam Pekerjaan sebelumnya kurang dioptimalkan $\sim 1 \mu \mathrm{m}$ thick silikon oksida dan film oxynitride didukung oleh $\mathrm{Al}$ dan oleh foil polimer alumina. Pilihan lainnya adalah dengan menggunakan lapisan gas terbatas $\mathrm{NH}_{3}, \mathrm{C}_{2} \mathrm{H}_{4}, \mathrm{C}_{2} \mathrm{H}_{4} \mathrm{O}$, atau campurannya (Claes G. Granqvist, 2016).

$$
\begin{gathered}
\mathrm{R}(\lambda)=1 \text { untuk } 3<\lambda<8 \mu \mathrm{m} \text { dan } 13<\lambda<50 \mu \mathrm{m} \\
\mathrm{R}(\lambda)=0 \text { untuk } 8<\lambda<13 \mu \mathrm{m}
\end{gathered}
$$

Penurunan suhu lebih lanjut dimungkinkan melalui kontrol apertur untuk memastikan bahwa pertukaran radiasi terjadi terutama di arah puncak. Jika pendinginan harus dilakukan juga pada siang hari, diinginkan untuk memaksimalkan Rsol. Perhitungan telah menunjukkan bahwa permukaan selektif inframerah dapat menghasilkan daya pendinginan antara 60 dan $95 \mathrm{Wm}^{-2} \mathrm{k}^{-1}$ tergantung pada kondisi di atmosfer. Suhu maksimum penurunan $26^{\circ} \mathrm{C}-60^{\circ} \mathrm{C}$ dengan pertukaran radiasi, dan $18^{\circ} \mathrm{C}-$ $34^{\circ} \mathrm{C}$ untuk aliran panas non-radiasi sebesar $1 \mathrm{Wm}^{-2} \mathrm{~K}^{-1}$ telah dihitung. Oleh karena itu, selektivitas spektral sangat penting untuk mencapai suhu yang rendah (López-Herraiz et al., 2017).

\subsection{Coatings for Glazing: Static Properties}

Fungsi utamanya adalah memberikan kontak visual antar dalam ruangan dan di luar ruangan serta pencahayaan alami, dan oleh karena itu area berkaca harus jangan terlalu kecil. Konsekuensi dari fakta ini adalah aliran energi yang tidak diinginkan dengan energi panas yang berlebihan keluar atau memasuki gedung melalui mereka kaca, yang menyebabkan kebutuhan untuk pemanasan dan pendinginan yang menghabiskan energi (Jelle, 2015).

Tren dalam teknik arsitektural adalah meningkatkan area kaca sehingga masalah energi yang terkait dengan kaca dapat mengakibatkan masalah yang buruk di masa depan. Bagian radiasi dari perpindahan panas dapat dikurangi melalui pengenceran film dengan $\mathrm{E}_{\text {therm }}$ rendah yang, dalam kaca multipane, harus menghadap salah satu ruang udara (atau gas) tertutup. Perpindahan panas melintasi jendela yang dipasang secara vertikal dapat turun dari $\sim 3$ hingga $\sim 1,5 \mathrm{Wm}^{-2} \mathrm{~K}^{-1}$ untuk kaca panel ganda dan dari $\sim 1,8$ hingga $\sim 1,0 \mathrm{Wm}^{-2} \mathrm{~K}^{-1}$.

Untuk triplepane kaca ketika salah satu panel memiliki lapisan dengan $\mathrm{E}_{\text {therm }}$ rendah. ini jelas bahwa Tlum pasti besar untuk film-film ini. Bagian inframerah dari radiasi matahari yang mengangkut 
Vol. 1, No. 3, pp $68-77$

doi: $10.14710 /$ jebt.2020.10059

energi melalui kaca tetapi tidak dilihat oleh mata dapat dipotong oleh film tipis dengan reflektansi tinggi pada $0,7<\lambda<3 \mu \mathrm{m}$. Film-film tersebut dihantarkan secara elektrik dan karenanya sesuai sebagai elektroda transparan untuk elektrokromik dan perangkat fotovoltaik (Pittaluga, 2015). Persyaratan ini telah menyebabkan perkembangan dua hal yang berbeda dalam jenis film tipis. Salah satunya dikenal sebagai "lapisan emisi rendah" (low-E coating) dan idealnya ditandai dengan persamaan:

$$
\begin{aligned}
& \mathrm{T}(\lambda)=1 \text { untuk } 0,4<\lambda<3 \mu \mathrm{m} \\
& \mathrm{R}(\lambda)=1 \text { untuk } 3<\lambda<50 \mu \mathrm{m}
\end{aligned}
$$

sedangkan tipe lainnya disebut "solar control coating" dan idealnya karakteristik oleh persamaan:

$$
\begin{aligned}
& \mathrm{T}(\lambda)=1 \text { untuk } 0,4<\lambda<0,7 \mu \mathrm{m} \\
& \mathrm{R}(\lambda)=1 \text { untuk } 0,7<\lambda<50 \mu \mathrm{m}
\end{aligned}
$$

\subsection{Electrochromic Thin Films And Devices}

Perangkat elektrokromik dapat memodulasi $\mathrm{T}_{\mathrm{lum}}$ dan $\mathrm{T}_{\mathrm{sol}}$ di bawah aksi dari tegangan rendah (Mortimer et al., 2015). Oleh karena itu mereka dapat mengontrol jumlah energi yang masuk melalui kaca "pintar" dan menurunkan kebutuhan untuk pendingin udara di gedung-gedung berpendingin. Efisiensi energi disediakan oleh teknologi ini dapat menjadi substansial mengingat bahwa strategi pengendalian yang tepat. Selanjutnya, kontrol transmitansi bisa mengurangi silau dan memberikan lingkungan dalam ruangan yang lebih baik. Absorptance bukan daripada reflektansi biasanya dimodulasi sehingga kaca elektrokromik cenderung memanas dalam keadaan transparan rendah, yang harus diperhitungkan dalam konstruksi praktis. Pada prinsipnya, itu layak untuk dilakukan memodulasi Etherm (Pittaluga, 2015).

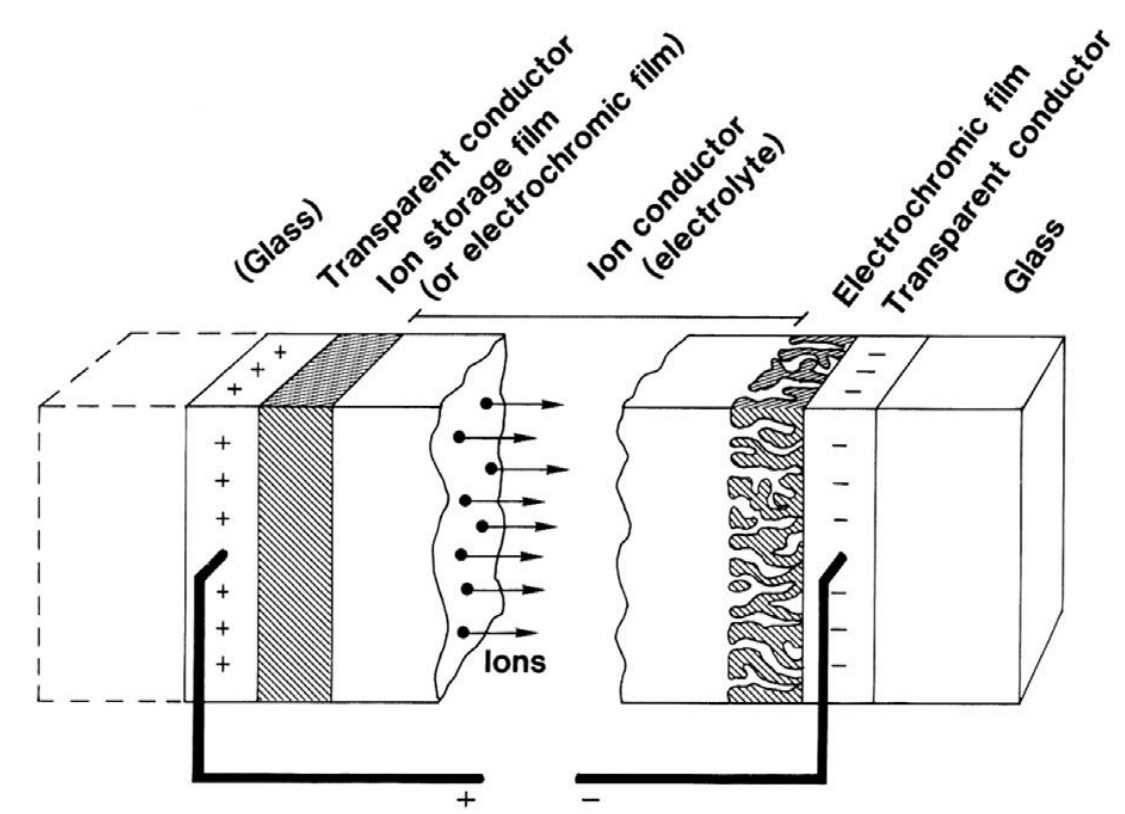

Gambar 4. Desain Perangkat Elektrokromik Generik, Panah Menunjukkan Transportasi Positif Ion dalam Medan Listrik (Wàckelgard et al., 2001) 
Gambar 4 menunjukkan perangkat lima lapisan elektrokromik generik dan memperkenalkan fitur desain dasar dan jenis bahan. Prinsip kesamaan dengan baterai listrik harus diperhatikan. Bagian tengah perangkat adalah konduktor ionik murni (elektrolit), baik film tipis atau polimer; itu harus menjadi konduktor yang baik untuk ion kecil seperti $\mathrm{H}^{+}$atau $\mathrm{Li}^{+}$. Elektrolit bergabung dengan film elektrokromik dan elektroda lawan film. Untuk perangkat transparan, elektroda kontra harus tetap ada tidak menyerap terlepas dari kandungan ioniknya atau harus elektrokromik dalam arti yang berlawanan dengan film elektrokromik dasar. Itu struktur tiga lapisan pusat diposisikan di antara listrik transparan konduktor, Penerapan beberapa volt antara konduktor transparan misalnya dengan menggunakan sel surya menyebabkan ion bergerak masuk atau keluar dari film elektrokromik yang memiliki sifat optik kemudian dimodifikasi sehingga transmisi optik keseluruhan harus diubah.

Prinsipnya, tegangan hanya dibutuhkan ketika transmitansi berubah, yaitu kaca elektrokromik dapat menunjukkan memori sirkuit terbuka dan karenanya menjadi hemat energi. Waktu untuk transisi antara tinggi dan transmitansi rendah terutama diatur oleh hambatan listrik konduktor transparan. Kaca "pintar" saat ini, dengan area meter persegi, membutuhkan waktu sekitar sepuluh menit untuk mengubah dari transparan menjadi agak gelap, yang memungkinkan mata untuk beradaptasi dengan cahaya. Elektrokromik yang lebih kecil perangkat dapat mengubah sifat optiknya lebih cepat. Banyak bahan dan masalah desain yang menarik untuk elektrokromik praktis Kaca "pintar" (Tian et al., 2017).

\section{Kesimpulan}

Artikel ini menyajikan beberapa jenis bahan dan material untuk memanfaatkan energi matahari untuk aplikasi termal. Tahap perkembangan eksplorasi dari fase awal hingga teknologi dewasa ini. Penelitian yang sedang berlangsung dimasa depan akan memperluas cakupan materi ini. Kolektor surya untuk memproduksi air panas atau udara banyak digunakan hari ini. Permukaan absorber selektif spektral telah dikembangkan dan disempurnakan selama beberapa dekade, dan banyak permukaan semacam ini diproduksi secara industri. Properti mereka mendekati batas teoritis. Teknologi manufaktur tampaknya telah bergeser ke dalam kondisi vakum metode dalam lingkungan kecil. Selain performa tinggi Peredam surya, yang pasti terlihat hitam, sedang berlangsung pengembangan permukaan berwarna yang agak kurang efisien yang meminjamkan diri mereka sendiri dengan baik untuk integrasi dalam arsitektur biasa. Permukaan seperti itu dapat diterapkan dengan mengecat dan teknologi berbiaya rendah serupa. Sebuah Tren perkembangan paralel menyangkut lapisan penyerap matahari dengan suhu tinggi dan dirancang untuk produksi listrik tenaga surya.

Teknologi untuk atap dan dinding dingin akhirnya dikembangkan dan tidak diragukan lagi akan mengarah pada kondisi kehidupan yang lebih baik di daerah panas. Pendinginan radiatif dengan menggunakan langit cerah sebagai heat sink menjadi penelitian yang dikembangkan saat ini.

Di negara-negara industri saat ini, sekitar $30-40 \%$ yang primer energi digunakan untuk pemanasan, pendinginan, penerangan dan ventilasi bangunan dan peralatan listrik sehingga dapat menghasilkan energi yang bersih dan ramah lingkungan. 


\section{Daftar Pustaka}

Badan Pengkajian dan Penerapan Teknologi. (2019). Indonesia Energy Outlook 2019: The Impact of Increased Utilization of New and Renewable Energy on the National Economy. Pusat Pengkajian Industri Proses dan Energi (PPIPE).

Badan Pusat Statistik. (2018). Statistik Lingkungan Hidup Indonesia (SLHI) 2018 (Subdirektorat Statistik Lingkungan Hidup (ed.)). Badan Pusat Statistik. https://doi.org/3305001

Barranco, A., Borras, A., Gonzalez-Elipe, A. R., \& Palmero, A. (2016). Perspectives on oblique angle deposition of thin films: From fundamentals to devices. Progress in Materials Science, 76, 59153. https://doi.org/https://doi.org/10.1016/j.pmatsci.2015.06.003

Choy, T. C. (2015). Effective Medium Theory: Principles and Applications. In International Series of Monographs on Physics (2nd ed.). Oxford University Press. https://doi.org/10.1093/acprof:oso/9780198705093.001.0001

Granqvist, C G. (2003). Solar Energy Materials. Advanced Materials, 15(21), 1789-1803. https://doi.org/https://doi.org/10.1002/adma.200300378

Granqvist, Claes G. (2016). Electrochromics and Thermochromics: Towards a New Paradigm for Energy Efficient Buildings. Materials Today: Proceedings, 3(Icfmd 2015), S2-S11. https://doi.org/10.1016/j.matpr.2016.01.002

Granqvist, Claes G., \& Niklasson, G. A. (2018). Solar energy materials for thermal applications: A primer. Solar Energy Materials and Solar Cells, 180(February), 213-226. https://doi.org/10.1016/j.solmat.2018.02.004

Jelle, B. P. (2015). Electrochromic smart windows for dynamic daylight and solar energy control in buildings. Electrochromic Materials and Devices, 419-502.

Kylili, A., \& Fokaides, P. A. (2017). Chapter 2 - Methodologies for Selection of Thermal Insulation Materials for Cost-Effective, Sustainable, and Energy-Efficient Retrofitting. In Fernando Pacheco-Torgal, C.-G. Granqvist, B. P. Jelle, G. P. Vanoli, N. Bianco, \& J. Kurnitski (Eds.), CostEffective Energy Efficient Building Retrofitting (pp. 23-55). Woodhead Publishing. https://doi.org/https://doi.org/10.1016/B978-0-08-101128-7.00002-2

López-Herraiz, M., Fernández, A. B., Martinez, N., \& Gallas, M. (2017). Effect of the optical properties of the coating of a concentrated solar power central receiver on its thermal efficiency. Solar $\begin{array}{lllll}\text { Energy Materials } & \text { Cells, }\end{array}$ https://doi.org/https://doi.org/10.1016/j.solmat.2016.08.031

Mortimer, R. J., Rosseinsky, D. R., \& Monk, P. M. S. (2015). Electrochromic Materials and Devices. In Electrochromic Materials and Devices. https://doi.org/10.1002/9783527679850

Niklasson, G. A., \& Granqvist, C. G. (1984). Optical properties and solar selectivity of coevaporated Co-Al2O3 composite films. Journal of Applied Physics, 55(9), 3382-3410. https://doi.org/10.1063/1.333386

Pittaluga, M. (2015). 17 - Electrochromic glazing and walls for reducing building cooling needs. In F Pacheco-Torgal, J. A. Labrincha, L. F. Cabeza, \& C.-G. Granqvist (Eds.), Eco-Efficient Materials for Mitigating Building Cooling Needs (pp. 473-497). Woodhead Publishing. https://doi.org/https://doi.org/10.1016/B978-1-78242-380-5.00017-0

Sani, E., Meucci, M., Mercatelli, L., Balbo, A., Musa, C., Licheri, R., Orrù, R., \& Cao, G. (2017). Titanium diboride ceramics for solar thermal absorbers. Solar Energy Materials and Solar Cells, 169, 313-319. https://doi.org/https://doi.org/10.1016/j.solmat.2017.05.038 
Vol. 1, No. 3, pp $68-77$

doi: $10.14710 /$ jebt.2020.10059

Soum-Glaude, A., Le Gal, A., Bichotte, M., Escape, C., \& Dubost, L. (2017). Optical characterization of TiAlNx/TiAlNy/Al2O3 tandem solar selective absorber coatings. Solar Energy Materials and Solar Cells, 170, 254-262. https://doi.org/https://doi.org/10.1016/j.solmat.2017.06.007

Tian, Y., Zhang, X., Dou, S., Zhang, L., Zhang, H., Lv, H., Wang, L., Zhao, J., \& Li, Y. (2017). A comprehensive study of electrochromic device with variable infrared emissivity based on polyaniline conducting polymer. Solar Energy Materials and Solar Cells, 170, 120-126. https://doi.org/https://doi.org/10.1016/j.solmat.2017.05.053

Wàckelgard, E., Niklasson, G. A., \& Granqvist, C. G. (2001). Selectively solar-absorbing coatings. In J. Gordon (Ed.), Solar Energy: The State of the Art (1st Edition, pp. 109-144). James \& James. 